\title{
Resaerch Paper: Effectiveness of Happiness Training on the Pattern of Parent-Child Relationships and the Hope of Parents With Autistic Children
}

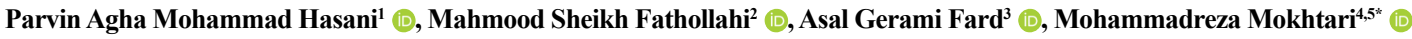 \\ 1. Department of Psychiatry, Clinical Research Development Unit (CRDU), Moradi Hospital, Rafsanjan University of Medical Sciences, Rafsanjan, Iran \\ 2. Department of Epidemiology, Biostatistics and Occupational Environment Research Center, School of Medicine, Rafsanjan University of Medical \\ Sciences, Rafsanjan, Iran. \\ 3. Clinical Research Development Unit (CRDU), Moradi Hospital, Rafsanjan University of Medical Sciences, Rafsanjan, Iran. \\ 4. Department of Psychology and Education, Kerman Branch, Islamic Azad University, Kerman, Iran. \\ 5. Social Determinants of Health Research Center, Rafsanjan University of Medical Sciences, Rafsanjan, Iran.
}

\begin{tabular}{|c|c|}
\hline $\begin{array}{l}\text { Use vour device to san } \\
\text { and read the article online }\end{array}$ & dtat on:Agha Mohammad Hasani P. Sheikh Fathollahi M. Gerami Fard A. Mokhtaree M. Effectiveness of Happiness Train- \\
\hline 口ipt四 & ing on the Pattern of Parent-Child Relationships and the Hope of Parents With Autistic Children Iranian Rehabilitation Journal. \\
\hline tritst & 2020; 18(3):309-318. http://dx.doi.org/10.32598/irj.18.3.946.1 \\
\hline 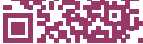 & dol'http://dx.doi.org/10.32598/irj.18.3.946.1 \\
\hline
\end{tabular}

(c) (i) (8)

Article info:

Received: 31 Aug 2019

Accepted: 13 Aug 2020

Available Online: 01 Sep 2020

Keywords:

Happiness, Parent-child relationship, Hope, Autism

\section{A B STRACT}

Objectives: Families of children with special needs face many problems. This study aimed to investigate happiness training on the pattern of parent-child relationships and the hope of parents with autistic children.

Methods: Twenty-six couples with autistic children who referred to Rafsanjan Autism Clinic, Rafsanjan City, Iran, were enrolled in the study by the census method. Informed consent was obtained from them. Then the parents completed the Schaefer and Edgerton Parent-Child Interaction Questionnaire (1985) and Miller Hope Scale (1988). Next, parents were randomly assigned to the intervention or control groups. Happiness training based on the Fordyce method was performed for eight 1.5-hour sessions per week for the intervention group. The parents of either group completed the questionnaires after training of the intervention group (about 2 months and 3 months later). The Chi-square test, independent t-test, and 2-way repeatedmeasures ANOVA were used for statistical analysis. The level of significance was set at 0.05 .

Results: The results of the analysis showed that the changes in the scores of communication $(\mathrm{P}=0.013)$, acceptance $(\mathrm{P}=0.008)$, control $(\mathrm{P}=0.005)$, independence $(\mathrm{P}=0.040)$, aggressive nonattachment $(\mathrm{P}=0.015)$, and hope $(\mathrm{P}=0.010)$ were significant between the two groups at stages of measurement. The scores of all variables increased but the aggressive non-attachment decreased.

Discussion: The education of happiness in Fordyce style influenced the interactive pattern of communication and hope of parents with autistic children. Therefore, training of happiness along with other services available to parents of autistic children can also be considered.

\section{* Corresponding Author:}

Mohammadreza Mokhtaree, PhD.

Address: Department of Psychology and Education, Kerman Branch, Islamic Azad University, Kerman, Iran.

Tel: +98 (34) 34260080

E-mail: mrmokhtaree@yahoo.com 


\section{Highlights}

- Happiness training influences the parent-child relationships of parents with autistic children.

- Happiness training influence the hope of parents with autistic children.

\section{Plain Language Summary}

Happiness training is effective in parent-child interaction and parents' hope of having a child with autism.

\section{Introduction}

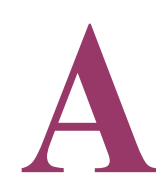

ccording to the definition, autism is a developmental disorder in children with abnormal verbal-communication and repetitive behaviors. The disorder symptoms appear before three years old. This disorder causes the brain to fail to function properly in social behaviors and communication skills and disturbs the child's communication and interaction with others [1]. Autism spectrum disorders have strong genetic sources [1, 2], with $15 \%-40 \%$ cases of the disease being inherited through genes [2]. There is no detailed information for the prevalence and distribution of autism; however, the Diagnostic and Statistical Manual of Mental Disorders, the Fifth Edition, estimates the prevalence of autism spectrum disorder in the United States and other countries to be approximately 10-30 cases per 10000 persons. Furthermore, this disorder has been reported to be 4 to 5 times more prevalent in boys than in girls, even though, the disorder in girls is associated with more severe mental retardation [3].

One of the major problems in autistic children is their difficulty in social communication [1] and such social communication disorder can be regarded as the most significant, the most important, and the main feature of autism. On the other hand, the child's problem in establishing effective communication also affects the child-parents' relationship. Mothers with autistic children are depressed and sad, and somehow blame themselves for their child's problems, feel guilty, and suffer from continuous anxiety [4]. Families of children with autism spectrum disorders seem to face various challenges and difficulties, including social isolation, depression, and anxiety [5].

Hope is a psychological structure influenced by numerous internal and environmental factors [6]. Parents with autistic children consider their hopes to be lost and their dreams to be faded. Over time, they lose their hope and have no organized and purposeful plan for themselves and their child in the coming future because they believe that autism is a lasting disorder without definitive treatment [7].

The findings of previous studies have shown the relationship between hope and health. Hope consists of two cognitive and emotional components. The emotional component can predict future positive events and increase psychological well-being [8]. Happiness is one of the main essentials of mankind, which has a great impact on the formation of personality and mental health [9]. According to Orstavik, happiness is a positive concept that is vital to provide and maintain health [10]. Some researchers have proved that a sense of happiness can be used to treat mental illnesses, increase hope, promote mental strength, and enhance defensive power against stress $[11,12]$. In this regard, Rashidi et al. reported that a positive psychological state increased the likelihood of happiness and relaxation [13]. Accordingly, it seems that providing parents with different training help them to accept their autistic child, reduce anxiety and depression, and increase their intrinsic and environmental happiness [14].

Fordyce, a theorist in the field of happiness, used an educational approach that is both cognitive and behavioral. In the cognitive aspect, he discussed the causes of specific thoughts and behaviors leading to happiness and adopted a variety of techniques and solutions from cognitive and behavioral therapies in the behavioral aspect. The Fordyce happiness training program is a strategy with 14 cognitive and behavioral components. Eight cognitive components of this strategy are as follows: decreasing expectations and desires, creating positive and optimistic thoughts, planning events, focusing on the present, reducing negative emotions, terminating discomfort, nurturing a healthy personality, and valuing happiness. Its 6 behavioral components are increasing activity, enhancing social interactions, fostering close relationships, nurturing social personality, creativity, and engaging in meaningful tasks. Fordyce studied the feasibility of promoting happiness, and suggested some relevant strate- 
gies, and tested them under controlled conditions. The results of his studies indicated that all proposed strategies improved happiness among the participants $[15$, 16]. Fathi et al. also found out that happiness training for parents with depressed children promoted their happiness, life satisfaction, and general health [17]. Happiness training also enhances general self-efficacy, reduces stress induced by educational activities, improves mental health [18], and promotes the quality of life and distress tolerance in individuals with physical disabilities [19]. Various studies have proposed that a child suffering from a disability lowers hopefulness in his parents [6]. Lloyd et al. also showed that mothers of children with intellectual disabilities scored lower on hope and mental health [20]. On the contrary, the findings of Koydemir et al. indicated that the psychological experiences of mothers with autistic children were similar to those of the mothers of children with other disabilities [21]. In the literature review, the researchers of the present study found no study on happiness training for the parents of autistic children. Therefore, the present study aimed to determine the effectiveness of the Fordyce happiness training program on the parent-child interaction model and hope in parents with autistic children.

\section{Methods}

The population of this educational trial comprised all parents (both fathers and mothers) of children with autism disorder referred to Rafsanjan Autism Teaching and Rehabilitation Center, Rafsanjan City, Iran, in 2019 $(\mathrm{N}=31)$. Twenty-six parents were enrolled in the study based on the inclusion criteria of 20-60 years old, without a history of psychiatric illness with hospitalization (e.g. schizophrenia, treatment-resistant major depression, and borderline personality disorder), without a history of chronic or severe physical illness (e.g. multiple sclerosis, developed cancer, and grand mal epilepsy), without a history of the death of relatives over the last year, divorce, or history of drug abuse. The exclusion criteria included incomplete participation in all training sessions.

After ethical approval, an introduction session was held for all parents. In this meeting, the purpose of the study was outlined, their informed consent was obtained, and demographic checklists including age, education level, and economic status were completed. Then, the parents completed the Schaefer and Edgerton Parent-Child interaction Questionnaire (SEPCQ) and the Miller Hope Scale (MHS).

SEPCQ consisted of 24 items measuring parents' perceptions of their relationship with their child based on 6 aspects (communication, acceptance, control, independence, aggressive control, aggressive non-attachment). In SEPCQ, parents describe their feelings, perceptions, or views on how they behave or interact with their child on a 5-point Likert scale. The Persian version of this questionnaire was validated in Iran. The Cronbach alpha coefficient of the scale was found as 0.89 [22].

Moreover, the MHS was developed by Miller and Powers to measure an individual's hopefulness [8]. The first scale consisted of 40 items, which was increased by 48 items in subsequent versions. The MHS is a type of diagnostic test comprising 48 aspects of hopelessness and helplessness, in which the items are listed based on explicit or implicit behavioral manifestations in hopeful or hopeless individuals. The items are scored based on a Likert-type scale. Each respondent is scored by selecting a sentence that comes true for him or her, according to what his or her life expectancy and helplessness are assessed. Total score ranges 48-240, with 48 indicating the highest level of hopelessness and 240 representing the

Table 1. Testing statistical assumptions

\begin{tabular}{|c|c|c|c|c|}
\hline Variables & BOX's M test & Levene's test & Shapiro-Wilk & Skewness-kurtosis \\
\hline Communication & 0.213 & 0.106 & 0.289 & $-0.061,-0.310$ \\
\hline Acceptance & 0.170 & 0.118 & 0.026 & $0.754,-0.289$ \\
\hline Control & - & 0.055 & 0.038 & $-0.442,-0.501$ \\
\hline Independence & 0.364 & 0.086 & 0.258 & $0.196,0.130$ \\
\hline Aggressive control & 0.400 & 0.196 & 0.535 & $0.325,0.003$ \\
\hline Aggressive non-attachment & 0.053 & 0.211 & 0.001 & $0.236,1.841$ \\
\hline Hope & 0.866 & 0.794 & 0.644 & $-0.100,-0.662$ \\
\hline
\end{tabular}


Table 2. Summary of the Fordyce happiness training method

\begin{tabular}{|c|c|c|c|c|}
\hline Sessions & Contents & Techniques & Objectives & Assignments \\
\hline 1 & $\begin{array}{l}\text { Defining autism and its symp- } \\
\text { toms, defining happiness, its } \\
\text { necessity, and importance }\end{array}$ & $\begin{array}{l}\text { Verbal training, } \\
\qquad \mathrm{Q} \& \mathrm{~A}\end{array}$ & $\begin{array}{l}\text { Introduction to discus- } \\
\text { sions and meetings }\end{array}$ & --- \\
\hline 2 & $\begin{array}{l}\text { Teaching techniques to increase } \\
\text { physical activity, be productive, } \\
\text { and do meaningful and useful } \\
\text { works }\end{array}$ & $\begin{array}{l}\text { Verbal training, } \\
\qquad \mathrm{Q} \& \mathrm{~A}\end{array}$ & $\begin{array}{l}\text { Doing useful and mean- } \\
\text { ingful works }\end{array}$ & $\begin{array}{l}\text { Increasing public and private activi- } \\
\text { ties (e.g. regulating sleeping hours and } \\
\text { having half an hour of daily exercise or } \\
\text { walking), increasing useful works }\end{array}$ \\
\hline 3 & $\begin{array}{l}\text { Training techniques for bet- } \\
\text { ter planning and organization, } \\
\text { avoiding worries, lowering ex- } \\
\text { pectations and desires }\end{array}$ & $\begin{array}{l}\text { Verbal training, } \\
\qquad \mathrm{Q} \& \mathrm{~A}\end{array}$ & $\begin{array}{l}\text { Application of tech- } \\
\text { niques for better plan- } \\
\text { ning and organization, } \\
\text { reducing expectations }\end{array}$ & $\begin{array}{l}\text { Performing the techniques taught in } \\
\text { the previous session, implementing } \\
\text { planning and prioritization techniques }\end{array}$ \\
\hline 4 & $\begin{array}{l}\text { Techniques of creativity, tech- } \\
\text { niques of living in the present }\end{array}$ & $\begin{array}{l}\text { Verbal training, } \\
\qquad \text { Q \& A }\end{array}$ & $\begin{array}{l}\text { Applying creative think- } \\
\text { ing techniques }\end{array}$ & $\begin{array}{l}\text { Performing the techniques taught in } \\
\text { the previous sessions, innovation in } \\
\text { daily activities, and doing some cre- } \\
\text { ative works }\end{array}$ \\
\hline 5 & $\begin{array}{l}\text { Training techniques for enhanc- } \\
\text { ing social relationships and be- } \\
\text { ing the real self }\end{array}$ & $\begin{array}{l}\text { Verbal training, } \\
\qquad \mathrm{Q} \& \mathrm{~A}\end{array}$ & $\begin{array}{l}\text { Increasing social rela- } \\
\text { tionships }\end{array}$ & $\begin{array}{l}\text { Performing the techniques taught in } \\
\text { the previous sessions, implementing } \\
\text { the real-self technique, and avoiding } \\
\text { complimentary comments }\end{array}$ \\
\hline 6 & $\begin{array}{l}\text { Training techniques for enhanc- } \\
\text { ing increasing intimacy as the } \\
\text { most important source of hap- } \\
\text { piness and techniques for priori- } \\
\text { tizing and valuing happiness }\end{array}$ & $\begin{array}{l}\text { Verbal training, } \\
\qquad \mathrm{Q} \& \mathrm{~A}\end{array}$ & $\begin{array}{l}\text { Parents should be able } \\
\text { to show their intimacy } \\
\text { with others }\end{array}$ & $\begin{array}{l}\text { Performing all the presented tech- } \\
\text { niques, increasing intimacy, and doing } \\
\text { practices to avoid dependence }\end{array}$ \\
\hline 7 & $\begin{array}{l}\text { Techniques for expressing feel- } \\
\text { ings and optimism }\end{array}$ & $\begin{array}{l}\text { Verbal training, } \\
\text { Q \& A }\end{array}$ & $\begin{array}{l}\text { Parents should be able } \\
\text { to express their feelings } \\
\text { toward others }\end{array}$ & $\begin{array}{l}\text { Performing all the techniques pre- } \\
\text { sented in previous sessions, expressing } \\
\text { emotions as much as possible }\end{array}$ \\
\hline 8 & A review of all the techniques & $\begin{array}{l}\text { Verbal training, } \\
\text { Q \& A }\end{array}$ & $\begin{array}{l}\text { Assessing individuals' } \\
\text { ability to be happy }\end{array}$ & -- \\
\hline
\end{tabular}

highest level of hopefulness. The Cronbach alpha coefficient of this scale was reported as 0.9. In Abolghasemi et al. study [23], it was found as 0.87 . Then the participants were randomly assigned to the intervention and control groups using randomly permuted blocks of size $2(n=13)$.

The intervention group received 8 1.5-hour sessions of the Fordyce happiness training per week [15, 24] (as a group) at Rafsanjan's Autism Teaching and Rehabilitation Center by a PhD candidate of Psychology (Table 1), while the control group received the routine services of the rehabilitation center.

After passing the training course, post-test and follow-up test were run for the intervention and control groups using the same instruments (namely SEPCQ and MHS). All participants were present until the end of the study and no one was excluded.

It should be noted that both parents of the affected child were included in this study and the necessary training was provided to both mothers and fathers so that the total score of the parents' interaction patterns and hope were considered in the statistical analysis [25].

The assessor and the statistical analyst were not aware of the classification of participants. The obtained data were analyzed using SPSS v. 18. Results for numeric data were reported as Mean $\pm \mathrm{SD}$ and as No. (\%) for categorical data. The Chi-square test was applied for categorical variables while the independent t-test was used for numeric variables. Two-way repeated-measures ANOVA was utilized to compare mean scores of parentchild interaction dimensions and hope across the two groups while adjusting for the pre-test effect. $\mathrm{P} \leq 0.05$ was considered a significant difference.

\section{Results}

The Mean \pm SD age of the children in the intervention group was $8.92 \pm 2.68$ years and in the control group was $7.86 \pm 2.25$ years $(\mathrm{t}=1.097, \mathrm{P}=0.283)$. The Mean $\pm \mathrm{SD}$ age of the fathers in the intervention group was 39.00 \pm 5.57 years and in the control group was $41.17 \pm 4.05$ years $(\mathrm{t}=$ $1.095, \mathrm{P}=0.284$ ). The Mean $\pm \mathrm{SD}$ age of the mothers in 
Table 3. Comparing the mean of research variables in two groups

\begin{tabular}{|c|c|c|c|c|c|c|c|}
\hline Variables & SS & df & MS & $\mathbf{F}$ & $\mathbf{P}$ & Eta 2 & Power \\
\hline Communication & 2.513 & 2 & 1.256 & 4.671 & 0.013 & 0.166 & 0.768 \\
\hline Acceptance & 2.00 & 2 & 1.00 & 5.333 & 0.008 & 0.182 & 0.816 \\
\hline Control & 3.026 & 2 & 1.513 & 5.939 & 0.005 & 0.198 & 0.858 \\
\hline Independence & 1.180 & 2 & 0.590 & 3.441 & 0.040 & 0.125 & 0.618 \\
\hline Aggressive control & 0.953 & 1.326 & 0.719 & 2.090 & 0.151 & 0.080 & 0.327 \\
\hline Aggressive non-attachment & 2.019 & 1.252 & 1.613 & 5.956 & 0.015 & 0.199 & 0.718 \\
\hline Hope & 10.850 & 1.786 & 6.074 & 5.432 & 0.010 & 0.185 & 0.790 \\
\hline
\end{tabular}

the intervention group was $35.42 \pm 3.82$ years and in the control group was $36.14 \pm 3.82$ years $(\mathrm{t}=-0.483, \mathrm{P}=0.634)$.

Of 12 children in the first group, $8(66.7 \%)$ were boys, and of the 14 children in the control group, $9(64.3 \%)$ were boys $(\mathrm{x}=0.016, \mathrm{P}=0.899)$. The frequency of fathers' education $(\mathrm{x}=4.616, \mathrm{P}=0.099)$, the level of mothers' education $(\mathrm{x}=2.860, \mathrm{P}=0.239)$, and the economic status $(\mathrm{x}=0.851$, $\mathrm{P}=0.653$ ) of the two groups were not significant.

In this study, the independent t-test and two-way repeated-measures ANOVA was used for the inferential analysis of the data. The statistical assumptions were examined, and the data normality was confirmed. The skewness and kurtosis of parent-child interaction dimensions and hope were between +2 to -2 . The normality of the score distribution was then assessed (Table 2). The mean scores of the parent-child interaction dimensions and hope are presented in Table 2.

Two-way repeated-measures ANOVA was used to analyze the data with regard to the type of study (i.e. a trial study) as well as the small sample size and the values of skewness and kurtosis. The results showed that for the variable of communication (one of the dimensions of the parent-child interaction model) $\mathrm{F}=4.405(\mathrm{P}=0.018)$; therefore, there was found a significant difference between the mean scores of "relationship" in the control and intervention groups so that happiness training significantly increased the parents' child "communication." The Eta-squared $\left(\eta^{2}\right)$ index indicated that $15.5 \%$ of the observed difference between the intervention and control groups with regard to the variable of communication could be explained as the effect of happiness training. Furthermore, the results showed that happiness training increased the scores of "acceptance" $(\mathrm{F}=5.735$, $\mathrm{P}=0.020)$, "control" $(\mathrm{F}=6.472, \mathrm{P}=0.012)$, “indepen- dence" $(\mathrm{F}=5.640, \mathrm{P}=0.014)$ and "hope" $(\mathrm{F}=14.498$, $\mathrm{p}=0.001)$, and decreased the "aggressive non-attachment” $(\mathrm{F}=9.703, \mathrm{P}=0.003)$ (Table 3).

\section{Discussion}

The present study aimed to determine the effect of happiness training on parent-child interaction patterns and hopefulness in parents with autistic children.

The results of the study suggested that happiness training for the parents of children with autism affected some of their interactive patterns such as communication, independence, aggressive control, and aggressive nonattachment. In this regard, happiness training increased the parent's hopefulness. The study findings showed that happiness training has a positive effect on the parents' relationship with their children. Sadeghi et al. found that CPRT (child-parent relationship therapy) for mothers had a positive and significant effect on the quality of parent-child interactions and mothers' happiness [26]. Shokohiyekta et al. documented that training new parenting techniques improved parent-child interaction [27]. Rasouli et al. found that cognitive-behavioral happiness training was effective in reducing the symptoms of children with attention deficit hyperactivity disorder [28].

In the present study, happiness training significantly reduced the parents' aggressive control (one of the dimensions of the interaction model). From this perspective, the finding of this study was in line with that of Kamarzarin's study [29]. If aggressive control is greater, the severity of impulsivity and disobedience symptoms in children increases. This is due to the negative and specific technique of control applied through violence and aggression and leads to resistance, and subsequently tensions, and hostility. The aggressive non-attachment of the interaction 
Table 2. Mean scores of parent-child interaction dimensions and hope

\begin{tabular}{|c|c|c|c|}
\hline \multirow{2}{*}{ Variables } & \multirow{2}{*}{ Stage } & \multicolumn{2}{|c|}{ Mean $\pm S D$} \\
\hline & & The Intervention Group ( $n=12$ ) & The Control Group ( $n=14)$ \\
\hline & Pre-test & $14.92 \pm 1.83$ & $15.21 \pm 1.12$ \\
\hline \multirow[t]{3}{*}{ Communication } & Post-test & $15.58 \pm 1.83$ & $15.21 \pm 1.37$ \\
\hline & Follow-up & $15.75 \pm 1.65$ & $15.20 \pm 1.12$ \\
\hline & Pre-test & $14.25 \pm 1.91$ & $14.21 \pm 1.25$ \\
\hline \multirow[t]{3}{*}{ Acceptance } & Post-test & $14.75 \pm 1.71$ & $14.36 \pm 1.15$ \\
\hline & Follow-up & $14.75 \pm 1.54$ & $14.43 \pm 1.10$ \\
\hline & Pre-test & $14.83 \pm 1.85$ & $14.93 \pm 1.27$ \\
\hline \multirow[t]{3}{*}{ Control } & Post-test & $15.67 \pm 1.82$ & $15.01 \pm 1.47$ \\
\hline & Follow-up & $15.58 \pm 2.35$ & $14.92 \pm 1.27$ \\
\hline & Pre-test & $14.08 \pm 2.31$ & $14.28 \pm 1.54$ \\
\hline \multirow[t]{3}{*}{ Independence } & Post-test & $14.67 \pm 2.10$ & $14.28 \pm 1.49$ \\
\hline & Follow-up & $14.58 \pm 1.97$ & $14.21 \pm 1.62$ \\
\hline & Pre-test & $14.33 \pm 1.61$ & $14.21 \pm 2.26$ \\
\hline \multirow[t]{3}{*}{ Aggressive control } & Post-test & $13.58 \pm 1.16$ & $14.43 \pm 2.03$ \\
\hline & Follow-up & $13.92 \pm 1.50$ & $14.28 \pm 2.13$ \\
\hline & Pre-test & $13.92 \pm 1.31$ & $14.21 \pm 0.89$ \\
\hline \multirow[t]{3}{*}{ Aggressive non-attachment } & Post-test & $13.08 \pm 1.16$ & $14.36 \pm 0.93$ \\
\hline & Follow-up & $13.17 \pm 1.34$ & $14.28 \pm 0.99$ \\
\hline & Pre-test & $72.91 \pm 13.30$ & $74.07 \pm 13.85$ \\
\hline \multirow[t]{2}{*}{ Hope } & Post-test & $74.83 \pm 13.32$ & $73.93 \pm 13.90$ \\
\hline & Follow-up & $74.92 \pm 13.03$ & $73.36 \pm 14.28$ \\
\hline
\end{tabular}

model also reflects behaviors such as rejection, avoidance, and aggression, especially verbal aggression [30]. Unhappy parents seem to have difficulty with controlling their impulses, which can lead to coping behaviors in maladaptive children with communication problems. This situation would cause more aggression between parents and children. As such, increased happiness in parents significantly reduces bilateral aggression, even though, these parents face numerous economic, social, and occupational problems that need to be concerned [31]. Argyle, a happiness theorist, regards social communication as one of the components of happiness, and believes that the family has the strongest social communication links; hence, it can be noted that communication and interactive models are among the functions of the family, which influence the degree of happiness in individuals. In a happy environment, especially in family relationships and interactions, happiness greatly influences how individuals interact and ultimately establishes a happy and lasting emotional environment in the family [32].

In the present study, happiness training enhanced the level of hopefulness in parents with autistic children. From this point of view, this study supports Firuozeh Moqadam's et al. study as these researchers found that happiness training increased hope and that this effect 
was also observed at the follow-up phase [33]. Fordyce's studies also documented that happiness training increased happiness, terminated discomfort, coping with problems, and eliminated depression $[15,16]$. Saul et al. also reported that happiness restored confidence, happiness, and hope in individuals and provided them with capital for their life [34]. Regarding the effects of happiness, several studies have claimed that happiness would treat mental illnesses, increase hope, promote mental strength, and enhance the defense power against stress. Firozeh Moghadam et al. suggest that happiness could be used to treat mental illnesses, increase hope, and enhance efforts to improve living standards in healthy individuals [33].

Argyle argued that happiness can be used to improve mental health. Parents of children with special needs, especially children with autism, lose their hopes and thus feel guilty. Hope promotes the adaptation power and is a sign of mental health, and having a plan for real life with the real goals represents an individual's hope in life. One of the most important factors in human life is hope and effort to discover its hidden variables to improve life conditions [32]. Warr believed that the relationship between happiness and some of the psychological variables and constructs was mutual, indicating that increased happiness and good feelings would improve and increase hope in individuals and vice versa [35]. Hopeful people have a purposeful life, are more satisfied with their life, and feel happier because they assess their capabilities positively after achieving their predetermined goals, which leads to a greater sense of happiness [36].

The limitations found in this work are the small sample size, and lack of evaluation of other variables able to modify the capacity of establishing contacts with peers. Thus it is difficult to generalize the results to different types of population. It is recommended that similar studies be conducted on other communities such as parents of children with attention deficit hyperactivity disorder, aggression, delinquency, etc.

\section{Conclusion}

According to the study findings, the Fordyce happiness training program influences the interactive patterns of relationship and hope in parents with autistic children. Accordingly, in addition to the other services available to the parents of autistic children, happiness should be considered.

\section{Ethical Considerations}

\section{Compliance with ethical guidelines}

The study was approved by Iran's Clinical Trial Center (Code: IRCT20150317021497N3).

Funding

This research did not receive any specific grant from funding agencies in the public, commercial, or not-forprofit sectors.

\section{Authors' contributions}

Conceptualization: Parvin Agha Mohammad Hasani and Mahmood Sheikh Fathollahi; Data colletion: Asal Gerami Fard; Data analysis and Writing - original draft: Mohammadreza Mokhtaree; Writing - review \& editing: All authors.

\section{Conflict of interest}

The authors declared no conflict of interest.

Acknowledgments

The authors would like to appreciate Rafsanjan Autism Teaching and Rehabilitation Center.

\section{References}

[1] Kaplan HI, Sadock BJ. Kaplan and Sadock's Synopsis of psychiatry: Behavioral Sciences/Clinical Psychiatry. New York: Lippincott Willa and Wilkins; 2015. https://www. amazon.com/Kaplan-Sadocks-Synopsis-Psychiatry-Behavioral/dp/1609139712

[2] Schaefer GB, Mendelsohn NJ. Clinical genetics evaluation in identifying the etiology of autism spectrum disorders. Genetics in Medicine. 2008; 10(4):301-5. [DOI:10.1097/ GIM.0b013e31816b5cc9] [PMID] [PMCID]

[3] Tsai LY. Impact of DSM-5 on epidemiology of Autism Spectrum Disorder. Research in Autism Spectrum Disorders. 2014; 8(11):1454-70. [DOI:10.1016/j.rasd.2014.07.016]

[4] Bayrami M, Hassimi Nosratabad T, Besharat R, Movahedi Y, Kohpayma S. The study of the components of neuroticism among parents of autistic children, mental retarded and normal in the city of Tabriz. Journal of Exceptional Education. 2014; 9(122):17-27. http:/ / exceptionaleducation.ir/ article-1-269-en.html

[5] Aali S, yazdi SAA, Abdkhodae MS, Ghanaee A, Moharari F. [Developmental sunction of samilies with Autism spectrum disorder children compared with families with healthy 
children (Persian)]. Medical Journal of Mashhad University of Medical Sciences. 2015; 58(1):32-41. http://mjms.mums.ac.ir/ article_3768.html

[6] Berjis M, Hakim Javadi M, Taher M, Lavasani MG, Hossein Khanzadeh AA. [A comparison of the amount of worry, hope and meaning of life in the mothers of deaf children, children with autism, and children with learning disability (Persian)]. Journal of Learning Disabilities. 2013; 3(1):6-27. [DOI: JLD-3-1-92-7-1]

[7] Samadi SA. Timed interventions in autism spectrum disorders. $1^{\text {th }}$ ed. Tehran: Didar Pubication; 2016.

[8] Miller JF, Powers MJ. Development of an instrument to measure hope. Nursing Research. 1988; 37(1):6-10. [DOI:10.1097/00006199-198801000-00002] [PMID]

[9] Skuratovych P. The science of happiness: How psychology reveals the secrets of longevity, a healthy life, and positive emotions. California: Create Space; 2017.

[10] Ørstavik RE. Happiness and health. Tidsskr Nor Laegeforen. 2017; 137(9):591. [DOI:10.4045/tidsskr.17.0376] [PMID]

[11] Mehrabi Shahrzaei L, Vakilkhani Dehghani M, Motaghi F. Determine effectiveness of happiness education in increasing hope of elderly based on fordyce model; (case study: City of Isfahan). Kuwait Chapter of Arabian Journal of Business and Management Review. 2014; 4(1):477-82. [DOI:10.12816/0018928]

[12] Ghazavi Z, Mardany Z, Pahlavanzadeh S. Effect of happiness educational program on the level of stress, anxiety and depression of the cancer patients' nurses. Iranian Journal of Nursing and Midwifery Research. 2016; 21(5):534-40. [DOI:10.4103/1735-9066.193419] [PMID] [PMCID]

[13] Rashidi Kochi F, Najafi M, Mohammadyfar MA. [The role of positive psychological capital and the family function in prediction of happiness in high school students (Persian)]. Positive Psychology. 2016; 2(3):79-95. [DOI: 10.22108/PPLS.2016.21553]

[14] Ooi KL, Ong YS, Jacob SA, Khan TM. A meta-synthesis on parenting a child with autism. Neuropsychiatric Sisease and Treatment. 2016; 12:745-62. [DOI:10.2147/NDT.S100634] [PMID] [PMCID]

[15] Fordyce MW. Psychology of happiness. Cypress Lake Media Pub; 1993. https://www.amazon.com/Psychology-Happiness-Fordyce/dp/0944137229/ref=sr_1_fkmr0_1?dchild=1 \&keywords=Fordyce+MW.+Psychology + of + Happiness $\% 3 \mathrm{~A}+$ Cypress+Lake+Me\&qid=1607579871\&s=books\&sr=1-1-fkmr0

[16] Fordyce MW. A review of research on the happiness measures: A sixty second index of happiness and mental health Social Indicators Research. 1988; 20(4):355-81. [DOI:10.1007/ BF00302333]

[17] Fathi E, Neek Rahan G. The study of the effectiveness of seligman's happiness training on happiness, life satisfaction and general health of parents of first grade elementary school children and depression in their children. Chaharmahal \& Bakhtiaris of Police Science. 2016; 1395(15):57-74. http:/ / www. chb.jrl.police.ir/article_14977_en.html

[18] lavasani M, Rastgoo L, Azarniad A. [The effect of happiness cognitive-behavioral training on self-efficacy beliefs and academic stress (Persian)]. Journal of Cognitive Strategies in Learning. 2015; 2(3):1-18. https://asj.basu.ac.ir/article_1018 html?lang=en
[19] Nourbakhsh S, Ayadi N, Fayazi M, Sadri E. [Effectiveness of happiness training program based on fordyce cognitive behavioral theory on quality of life and ability to tolerate disorders of women with physical-motor disabilities (Persian)] Iranian Journal of Rehabilitation Research in Nursing. 2018; 4(2):35-43. http:/ /ijrn.ir/article-1-305-en.html

[20] Lloyd TJ, Hastings R. Hope as a psychological resilience factor in mothers and fathers of children with intellectual disabilities. Journal of Intellectual Disability Research. 2009; 53(12):95768. [DOI:10.1111/j.1365-2788.2009.01206.x] [PMID]

[21] Koydemir S, Tosun Ü. Impact of autistic children on the lives of mothers. Procedia-Social and Behavioral Sciences. 2009; 1(1):2534-40. [DOI:10.1016/j.sbspro.2009.01.447]

[22] karahmadi M, Tabaiean R, Afkhami -Aghda M. [Parental interaction patterns in children with ADHD and controls a comparative study (Persian)]. The Journal of Shahid Sadoughi University of Medical Sciences. 2007; 15(1):35-43. http://jssu.ssu.ac.ir/article-1-675-en.html

[23] Abolghasemi S, Saeadi S, Morri Najafi NM. [The effect of Guided Imagery and logo therapy on depression, anxiety and hopefulness in women with cancer in Ahwaz (Persian)]. Journal Woman and Cultur. 2010; 2(5):31-47. http://jwc.iauahvaz.ac.ir/article_523394.html

[24] Hemati Z, Mosavi Asl FS, Abbasi S, Ghazavi Z, Kiani D. Fordyce happiness program and happiness in mothers of children with a cleft lip and palate. Iranian Journal of Otorhinolaryngology. 2016; 28(89):399-405. [DOI: 10.22038/ IJORL.2016.7768]

[25] Ghavami SR, Borimnejad L, Seyedfatemi N, Haghani H. [The effect of parental role training on stress in the parents of hospitalized newborns in a neonatal intensive care unit (Persian)]. Journal of Hayat. 2017; 23(3):243-53. http:/ / hayat. tums.ac.ir/article-1-2002-en.html

[26] Sadeghi A, Aghamohammadian Shaarbaf HR, Abdekhodaei MS. [The effectiveness of training of play therapy to mothers (based onthe CPRT approach) on parent-child relationship quality andhappiness in the mothers (Msc dissertation) (Persian)]. Mashhad: Ferdowsi University of Mashhad, 2014. http://epl.um.ac.ir/index.php?group_ id $=1401 \&$ section_id $=0 \&$ prof_id $=100041 \&$ startingYear_ id $=1392 \&$ fac $=14 \&$ option $=$ com $\_$faculties\&controller $=$facultie s\&view $=$ theses\&319a3877249942b8da6c0641b049ca61=1\&li mit $=5 \&$ limitstart $=0$ \&lang $=\mathrm{fa}$

[27] Shokohiyekta M, Akbari zardkhaneh S, Parand A, Pooran F. [Developing Parent-Child Relationship by New Parenting Style Methods (Persian)]. Journal Of Psychological Models And Methods. 2013; 3(10):1-16.

[28] Rasouli R, Omidian M, Sameie F. [Efficacy of cognitivebehavior training to mothers with ADHD children on reducing attention deficit/hyperactivity disorder in children and increase the happiness of parents (Persian)]. Family Counseling and Psychotherapy. 2013; 3(3):469-91. http://fcp.uok. ac.ir/article_9636_en.html

[29] Kamarzarin H. The affection of fordyce happiness model on increasing martial satisfaction of mothers within children mental retardation. Middle Eastern Journal of Disability Studies. 2016; 6:62-7. http://jdisabilstud.org/article1-428-en.html 
[30] Amiri M, Movallali G, Nesaiyan A, Hejazi M, Assady Gandomani R. [Effect of behavior management training for mothers with children having ODD symptoms (Persian)]. Archives of Rehabilitation. 2017; 18(2):84-97. [DOI:10.21859/ jrehab-180284]

[31] Khakpour M, Nejat H, Karimian F, Mehrafarid M, Mortazavi S, Chenari T. Effect of fordyce happiness model on hardiness and marital adjustment in infertile couples. Journal of Nursing Education. 2017; 6(2):41-8. [DOI:10.21859/jne-06026]

[32] Argyle M. The Psychology of Happiness. $2^{\text {th }}$ ed. United Kingdom: Routledge; 2001. [DOI:10.4324/9781315812212]

[33] Firozeh Moghadam S, Borjali A, Sohrabi F. [The efficiency of happiness training to increase the hope in elderly people (Persian)]. Salmand: Iranian Journal of Ageing. 2014; 8(4):6772. http:// salmandj.uswr.ac.ir/article-1-542-en.html

[34] Saul S, Saul SR. The application of joy in group psychotherapy for the elderly. International Journal of Group Psychotherapy. 1990; 40(3):353-63. [DOI:10.1080/00207284.1990.1 1490613] [PMID]

[35] Ghanbarian M, Parmouz M, Rajabzadeh Z. [The relationship between the happiness and life expectancy among the students of medical sciences in Behbahan city (Persian)]. Journal of Fundamentals of Mental Health. 2016; 18(Special Issue):553-6. [DOI: 10.22038/JFMH.2016.8509]

[36] Witvliet CV, Richie FJ, Root Luna LM, Van Tongeren DR. Gratitude predicts hope and happiness: A two-study assessment of traits and states. The Journal of Positive Psychology. 2019; 14(3):271-82. [DOI:10.1080/17439760.2018.1424924] 
This Page Intentionally Left Blank 